\title{
Composting of common organic wastes using microbial inoculants
}

\author{
Ieshita Pan • Bomba Dam • S. K. Sen
}

Received: 2 May 2011/Accepted: 14 October 2011/Published online: 17 November 2011

(C) The Author(s) 2011. This article is published with open access at Springerlink.com

\begin{abstract}
It is important to use renewable resources to maximize crop yields and minimize the environmental hazards associated with chemical residues. Composting is an age old practice for the biological conversion of organic waste to a humus-like substance which can enhance physical, chemical and biological soil properties. To explore the effect of microorganisms in the composting process, three potent bacterial isolates were selected. Their morphological, cultural and biochemical characteristics were identified, and 16S rDNA studies identified isolates B1U/1 and D3L/1 as Bacillus subtilis and isolate RAT/5 as Pseudomonas sp. Common organic wastes were composted using the selected isolates individually and as a consortium. The $\mathrm{C} / \mathrm{N}$ ratio of each substrate reduced gradually to 25-30:1 within 120 days and remained constant thereafter. The reduction in $\mathrm{NH}_{4}^{+}$and $\mathrm{NO}_{3}^{-}$ion concentrations also indicated compost maturity after 120 days. The $\mathrm{pH}$ of the mature compost was typically $7.0 \pm 0.2$, and the $\mathrm{PO}_{4}^{-3}$ ion concentration was high throughout the decomposition process. This study describes the optimization of the composting process using a consortium of isolates from composted soil.
\end{abstract}

\section{Keywords Compost $\cdot \mathrm{C}: \mathrm{N}$ ratio $\cdot \mathrm{NH}_{4}-\mathrm{N} \cdot \mathrm{NO}_{3}-\mathrm{N}$}

\section{Introduction}

Environmental contamination has the potential to be a major threat to the survival of living organisms. The

I. Pan · B. Dam $\cdot$ S. K. Sen $(\bowtie)$

Microbiology Division, Department of Botany, Visva-Bharati, Santiniketan 731235, India

e-mail: sksenvb@rediffmail.com misuse of chemical fertilizers and pesticides can contribute to the deterioration of the environment (Kaosol 2009). Population migration to urban areas and urban development can also lead to the depletion of fossil fuels, generation of carbon dioxide and contamination of water resources, all of which can lead to environmental contamination. Contamination can affect soil fertility resulting in a loss of productivity, and this realization has led to the adoption of sustainable farming practices with the aim of reversing the declines in productivity and environmental protection (Wani et al. 1995; Gautam et al. 2010).

In India, nearly 700 million tons of organic waste is generated annually, leading to challenges for its safe disposal, with the waste being usually either burned or land filled (Bhiday 1994; Nagavallemma et al. 2006; Zeinhom et al. 2010). However, there are several naturally occurring microorganisms that are able to convert organic waste into valuable resources such as plant nutrients, and reduce the $\mathrm{C}: \mathrm{N}$ ratio to support soil productivity. These microorganisms are also important to maintain nutrient flows from one system to another and to minimize ecological imbalance (Novinsak et al. 2008; Umsakul et al. 2010).

Composting is a preferred and environmentally sound method whereby organic waste is reduced to organic fertilizer and soil conditioners through biological processes (Gautam et al. 2010; Alexander 1999). The high organic carbon content and biological activity of compost make it effective for applications such as erosion control and revegetation (Anastasi et al. 2005). The composting process involves three phases, and uses diverse microflora such as bacteria, fungi and mesophilic (Streptomyces rectus) and thermophilic Actinomycetes (Actinobifida chromogena (Thermomonospora fusca) Microbispora (Thermopolyspora) bispora, Therinomnonospora curvata, Thermoactinomyces sp.) eventually converting organic 
waste to humus (Buyuksonmez et al. 2000; Pedro et al. 2003; Schloss et al. 2003; Zeng et al. 2011). During the first phase there is an increase in carbon dioxide along with the temperature. The substrate is reduced due to the degradation of sugar and proteins by the action of mesophilic organisms (Hellmann et al. 1997; Schloss et al. 2003; Novinsak et al. 2008; Zeng et al. 2011). The second phase leads to an increase of the temperature in the compost piles from $45^{\circ} \mathrm{C}$ to approximately $70{ }^{\circ} \mathrm{C}$ and the mesophiles are replaced by thermophiles (Pedro et al. 2003; Schloss et al. 2003). Large numbers of pathogenic individuals are degraded during this time (Novinsak et al. 2008). The third phase begins with the decrease of temperature of the compost pile.

The quality and stability of compost is entirely dependent on its raw materials (Ranalli et al. 2001; Benito et al. 2003; Wang et al. 2004). During the composting process, various parameters including the $\mathrm{C}: \mathrm{N}$ ratio, composting temperature, $\mathrm{pH}$ of the finished product, moisture content, and the presence of potential pathogens such as coliform bacteria are used to assess the quality and stability of the compost (Wu and Ma 2002; Steger et al. 2007; Erickson et al. 2009; Al-Turki 2010; Fourti et al. 2011; Sanmanee et al. 2011).

This paper monitors the decomposition of common household organic waste with a microbial consortium to identify a suitable composting method. In particular, this paper focuses on the identification of suitable but cheap raw materials, processes that use minimal energy, and the selection of proper microorganisms to produce quality compost.

\section{Materials and methods}

Organism maintenance and preparation

Three bacterial isolates, Bacillus subtilis B1U/1, B. subtilis D3L/1 and Pseudomonas sp. RAT/5 were selected from more than two hundred isolates from diverse compost samples. The hydrolysers, Bacilli isolates B1U/1 and D3L/ 1 , were maintained on slants of medium containing $5.0 \mathrm{gL}^{-1}$ carboxy methyl cellulose, $2.0 \mathrm{gL}^{-1} \mathrm{NaNO}_{3}$, $1.0 \mathrm{gL}^{-1} \mathrm{~K}_{2} \mathrm{HPO}_{4}, 0.5 \mathrm{gL}^{-1} \mathrm{MgSO}_{4} \cdot 7 \mathrm{H}_{2} \mathrm{O}, 0.5 \mathrm{gL}^{-1} \mathrm{KCl}$, $2.0 \mathrm{gL}^{-1}$ peptone, and $15.0 \mathrm{gL}^{-1}$ agar, held at $\mathrm{pH} 7.0$ and $4{ }^{\circ} \mathrm{C}$. The nitrogen fixer, Pseudomonas isolate RAT/5 was maintained in a mannitol nitrogen free agar medium containing $15.0 \mathrm{gL}^{-1}$ mannitol, $0.5 \mathrm{gL}^{-1} \mathrm{~K}_{2} \mathrm{HPO}_{4}, 0.2 \mathrm{gL}^{-1}$ $\mathrm{MgSO}_{4} \cdot 7 \mathrm{H}_{2}, 0.1 \mathrm{gL}^{-1} \mathrm{CaSO}_{4}, 0.2 \mathrm{gL}^{-1} \mathrm{NaCl}, 5.0 \mathrm{gL}^{-1}$ $\mathrm{CaCO}_{3}$, and $15.0 \mathrm{gL}^{-1}$ agar held at $\mathrm{pH}$ 7.3.

To achieve successful and rapid composting, inoculation by bacteria was needed. The sterilized raw materials were inoculated with $2 \%$ broth inoculum $\left(10^{9} \mathrm{CFU} / \mathrm{mL}\right)$ of each of the isolates, individually. To check the combined activity of the isolates, a $1 \%$ broth inoculum containing $10^{7} \mathrm{CFU} / \mathrm{mL}$ of each isolate was used.

The hydrolytic potentials of the isolates B1U/1, D3L/1 and RAT/5, particularly the cellulose, amylase (Miller 1959) and protease (Anson 1938) activities were measured, and protein estimations were performed (Lowry et al. 1951). All organisms were checked for their nitrogen fixation ability by growing them in nitrogen free medium.

\section{Composting process}

Seven raw materials (common organic wastes), fruit wastes, vegetable wastes, leaves, hay, newspaper, wheat straw and rice husks, identified as substrates C1-C7, respectively, were used for the composting experiment, as the nature of the raw material directly affects the quality of final product (Lasaridi and Stentiford 1996). Initially $20 \mathrm{~g}$ of each waste substrate was used in the experiments. All substrate samples were sterilized and inoculated with $B$. subtilis B1U/1, B. subtilis D3L/1 or Pseudomonas sp. RAT/ 5 , both separately and in a consortium. The inoculated flasks were maintained at room temperature $\left(30 \pm 2{ }^{\circ} \mathrm{C}\right)$ and $45-50 \%$ moisture during composting. The composting process was conducted in triplicate and monitored for up to 6 months.

\section{Sampling and analysis}

Three sub-samples $(1 \mathrm{~g}$ each) were taken at day 1 of the composting process and every 15 days thereafter (Gillet 1986). The first sub-sample was stored at $4{ }^{\circ} \mathrm{C}$ to provide a sample library; the second sub-sample was used for the physicochemical analyses; and the third sub-sample was used for the microbiological analyses.

At each sampling period, physical characteristics including color by visual observation, moisture content by gravimetric analysis, odor by olfactory analysis and texture by coarseness evaluation, were determined.

At each sampling period, the $\mathrm{pH}$ was determined using $\mathrm{pH}$ meter (1:10, water:extract) and moisture content was calculated by a simple deduction of water loss. The chemical composition of the sub-samples was determined, including the organic carbon (Black 1965), nitrogen (Vogel 1961), phosphate (Jackson 1968) and potassium (Wen et al. 1997) concentrations.

\section{Statistical analysis}

All experiments were conducted in triplicate. The values reported in this paper are mean $\pm \mathrm{SD}$ (Snedecor and Cochran 1980). 


\section{Results and discussion}

Organism selection and characterization

Three isolates were selected based on their hydrolytic potentials from 200 isolates in a diverse soil habitat, for this decomposition study. The selected organisms were repeatedly tested for their ability to produce extracellular cellulase, amylase and protease, as Umsakul et al. (2010) reported that organisms involved in organic decomposition processes were able to produce high levels of hydrolytic enzymes.

Isolates B1U/1 and D3L/1 were identified as members of the Bacillus genus while isolate RAT/5 was identified as a Pseudomonas sp. based on their morphological and cultural characteristics and biochemical properties (data not shown). For the molecular characterization, nearly complete 16S rRNA gene sequences were determined for isolates B1U/1 (1,411 bp) and RAT/5 (1,370 bp) and these were compared with the non-redundant nucleotide database at the National Center for Biotechnology Information (NCBI) (Pearson and Lipman 1988). In a sequence analysis, isolates B1U/1 (Accession No. GU723510) and D3L/1 (Accession No. GU723508) showed a 100\% similarity with B. subtilis strains while isolate RAT/5 (Accession No. GU723511) showed a 99\% similarity with Pseudomonas sp. bacteria, with the Escherichia, Klebsiella, Aeromonas, Pseudomonas, Alcaligenes, Bacillus and Enterococcus genera most likely (Ishii et al. 2000). Pseudomonas sp. RAT/5 was able to grow in the complete absence of nitrogen, and was, therefore, classified as an atmospheric nitrogen fixer.

\section{Physical characteristics}

During the composting process, gradual changes of the textures of the raw materials were observed after 30 days, followed by the appearance of a black colored humus-like substance which developed after 120 days of decomposition. In this study, only wheat straw (substrate C6) was converted into compost within 75 days. No textural change was observed for the newspaper waste material.

The moisture content was allowed to reduce after 90 days, while the optimum amount of decomposition occurred after 120 days, and the process was monitored for up to 6 months. The moisture content was maintained at $40-60 \%$ by sequential watering to replace any water loss. Moisture appeared to be a key influencing factor for microbial activity (Anastasi et al. 2005), as low moisture contents inhibit the growth of beneficial microorganisms (Umsakul et al. 2010), while excess moisture can create anaerobic conditions, leading to the production of unpleasant odors and toxic volatile substances (Saidi et al. 2008).

Weight loss was observed during the compost formation process. The weight losses were calculated using a simple deduction method. The reduction in weight was more significant during the first 45 days, which is a similar result to those observed by Andrea et al. (1998), who measured a weight loss of $29 \%$, and Gautam et al. (2010) who observed weight loss over a 45-day period.

\section{Chemical characteristics}

\section{Nitrogen transformation during composting}

The $\mathrm{NH}_{4}-\mathrm{N}$ concentration decreased for all substrates at different rates. The $\mathrm{NH}_{4}-\mathrm{N}$ content in the different substrates ranges from 0.2 to $4.17 \%$, while the $\mathrm{NO}_{3}-\mathrm{N}$ ranges from 0.1 to $0.5 \%$. After 60 days of decomposition, variations were observed in the $\mathrm{NH}_{4}-\mathrm{N}$ and $\mathrm{NO}_{3}-\mathrm{N}$ concentrations (Fig. 1). Figure 1 also shows that for the substrate $\mathrm{C} 2$ (vegetable waste) with isolate B1U/1 and C5 (news paper waste) with isolate $\mathrm{RAT} / 5, \mathrm{NH}_{4}-\mathrm{N}$ concentration increased during the first 55 days followed by a sharp decrease, with a steady $\mathrm{NH}_{4}-\mathrm{N}$ concentration after 90 days. However, for substrate C3 (leaves) inoculated with isolate RAT/5, C5 (newspaper waste) with isolate B1U/1, and C7 (rice husks) with isolates $\mathrm{B} 1 \mathrm{U} / 1$ and $\mathrm{D} 3 \mathrm{~L} / 1$, a continuous increase in the $\mathrm{NH}_{4}-\mathrm{N}$ concentration was observed throughout the composting process. At the completion of the composting process, for all seven substrates, the relative proportions of the nitrogenous species $\left(\mathrm{NH}_{4}^{+} \mathrm{N}\right.$ and $\left.\mathrm{NO}_{3}^{-} \mathrm{N}\right)$ indicate that ammonia was converted to nitric acid by the following process, as also observed by Saidi et al. (2008).

$\mathrm{NH}_{4}^{+}+2 \mathrm{O}_{2} \rightarrow \mathrm{NO}_{3}+2 \mathrm{H}^{+}+\mathrm{H}_{2} \mathrm{O}$

$2 \mathrm{H}^{+}+2 \mathrm{NO}_{3}^{-} \rightarrow 2 \mathrm{HNO}_{3}$

\section{C/N ratio}

The initial organic carbon content was relatively high for each substrate, at between 20 and $80 \%$. The initial C:N ratios were $35: 1$ ( $\mathrm{C} 1$; fruit waste), 15:1 (C2; vegetable waste), 60:1 (C3; leaves), 50:1 (C4; hay), 125:1 (C5; newspaper waste), 128:1 (C6; wheat straw), and 76:1 (C7; rice husks), which is consistent with the observations of Hadas and Portnoy (1994). The C:N ratio gradually decreased for all substrates except $\mathrm{C} 2$, for which the $\mathrm{C}: \mathrm{N}$ ratio increased for the first 60 days and then remained steady (Fig. 2). The overall nitrogen loss during later stages of the composting process caused the increase in this $\mathrm{C}: \mathrm{N}$ ratio. Atkinson et al. (1996) reported that a reduction of $29 \%$ of the organic carbon content occurs during composting of organic waste; while a reduction of only $10 \%$ in 

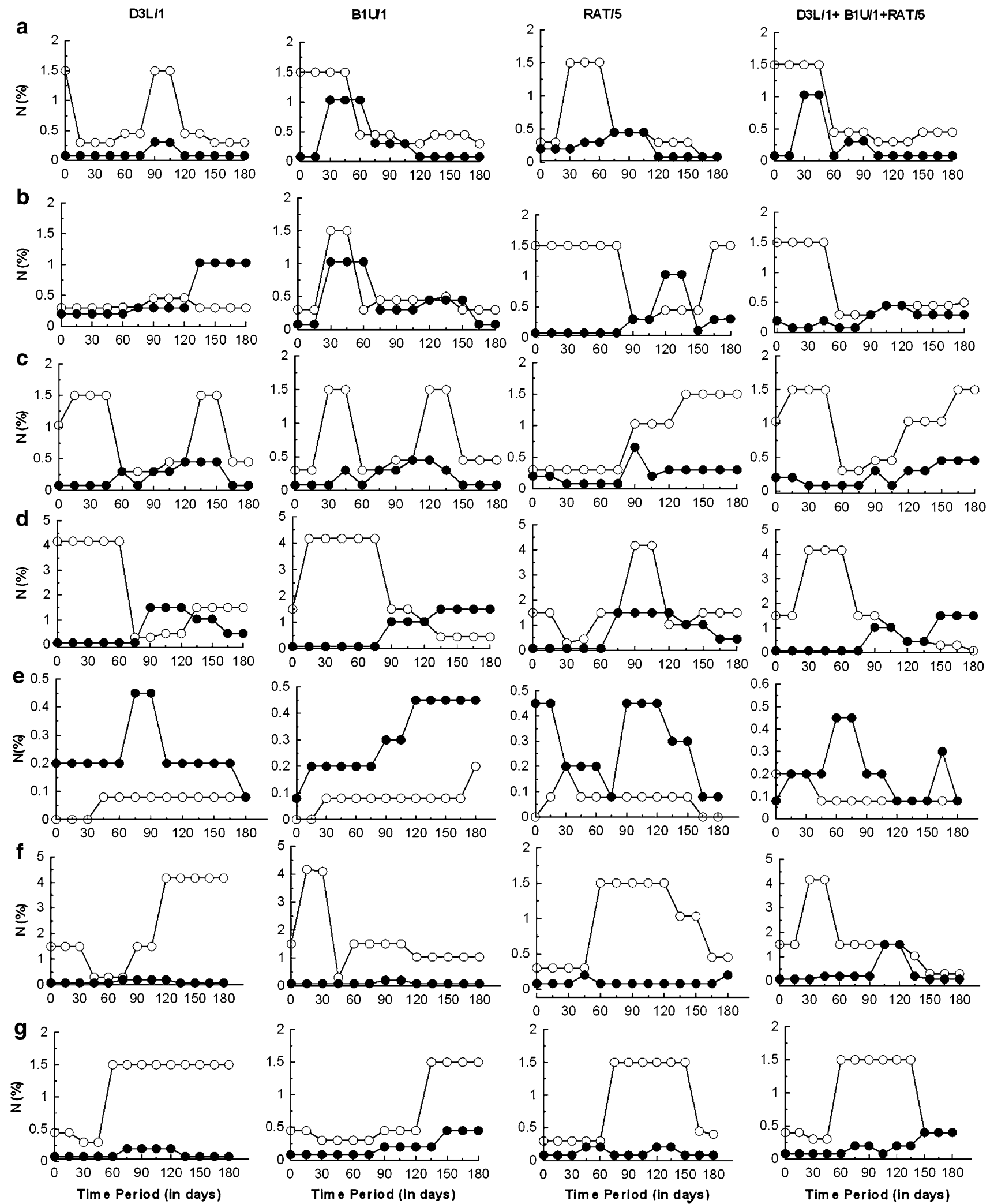

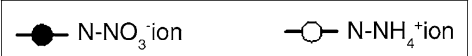

Fig. 1 Changes in nitrogen composition during the decomposition of different waste substrates: a fruit waste; $\mathbf{b}$ vegetable waste; $\mathbf{c}$ leaves; $\mathbf{d}$ hay; e newspaper waste; $\mathbf{f}$ wheat straw; $\mathbf{g}$ rice husks. Results are the mean value from three independent experiments 
the carbon content was estimated by Erickson et al. (2009) and Umsakul et al. (2010). In this study, the C:N ratio increased in some cases during the first 30 days of decomposition followed by a sharp decrease and was stable after 120 days, although this pattern varied depending on the test organism. When the consortium of three isolates $(1: 1: 1)$ was used, the rate of decomposition was faster and the $\mathrm{C}: \mathrm{N}$ ratio reduced to around $25-30: 1$ at $75-90$ days, depending on the substrate. The only exception was for C5 (newspaper waste) which required more than 180 days for the decomposition (Fig. 2d). Of the seven substrates tested, C6 (wheat straw) had a greatest increase in the rate of decomposition while using the bacterial consortium (Fig. 2d).

The decrease in the C:N ratio can be explained by the transformation of organic carbon into carbon dioxide, followed by a reduction in the organic acid content (Chefetz et al. 1998; Sanmanee et al. 2011). Saidi et al. (2008) reported that a stable $\mathrm{C}: \mathrm{N}$ ratio could be achieved after 95 days of decomposition. High C:N ratios can indicate the presence of unutilized complex nitrogen substrates (Saidi et al. 2008; Fourti et al. 2011), while low C:N ratios (less than 20:1) indicate the instability of the compost (Haug 1993). The completion of the composting process (compost maturity) is indicated when the $\mathrm{C}: \mathrm{N}$ ratio reduces to between 25 and 30:1 (Fig. 2d) (Hardy et al. 1993).

\section{pH changes during composting}

The changes in $\mathrm{pH}$ change during the composting process are shown in Fig. 3. The initial $\mathrm{pH}$ values were between 4.0 and 9.0, depending on the substrate. In the first 60 days of composting, a pH increase was observed for substrates $\mathrm{C} 3$ (leaves; inoculated with $\mathrm{B} 1 \mathrm{U} / 1$ ) and $\mathrm{C} 1$ (fruit waste; inoculated with the consortium). The $\mathrm{pH}$ increase is the result of volatilization and microbial decomposition of organic acids, and the release of ammonia by microbial mineralization of organic nitrogen sources (Mckinley and Vestal 1985). For substrates C2 (vegetable waste) and C4 (hay) inoculated with the consortium, and C6 (wheat straw) with $\mathrm{RAT} / 5$, an initial drop in the $\mathrm{pH}$ was recorded in the first 30 days. A similar $\mathrm{pH}$ drop was observed by Poincelot (1974), and White et al. (1995) suggested that an alkaline $\mathrm{pH}$ could enhance the composting process, controlling pathogenic fungi that prefer acidic growth conditions (Saidi et al. 2008). The decomposition of organic wastes at $\mathrm{pH}$ values of 6.0 or below can slow down the decomposition process, while $\mathrm{pH}$ values above 8.0 can cause the release of unpleasant smells associated with ammonia. Earlier studies have identified that microbial activity enhanced the likelihood of achieving a suitable $\mathrm{pH}$ range of 5.5-9.0; while the composting process is most effective at $\mathrm{pH}$ values between 6.5 and 8.0 (Christian et al. 1997). The $\mathrm{pH}$ value stabilized
Fig. 2 Change in C:N ratio for different waste substrates during composting. Results are the mean value from three independent experiments
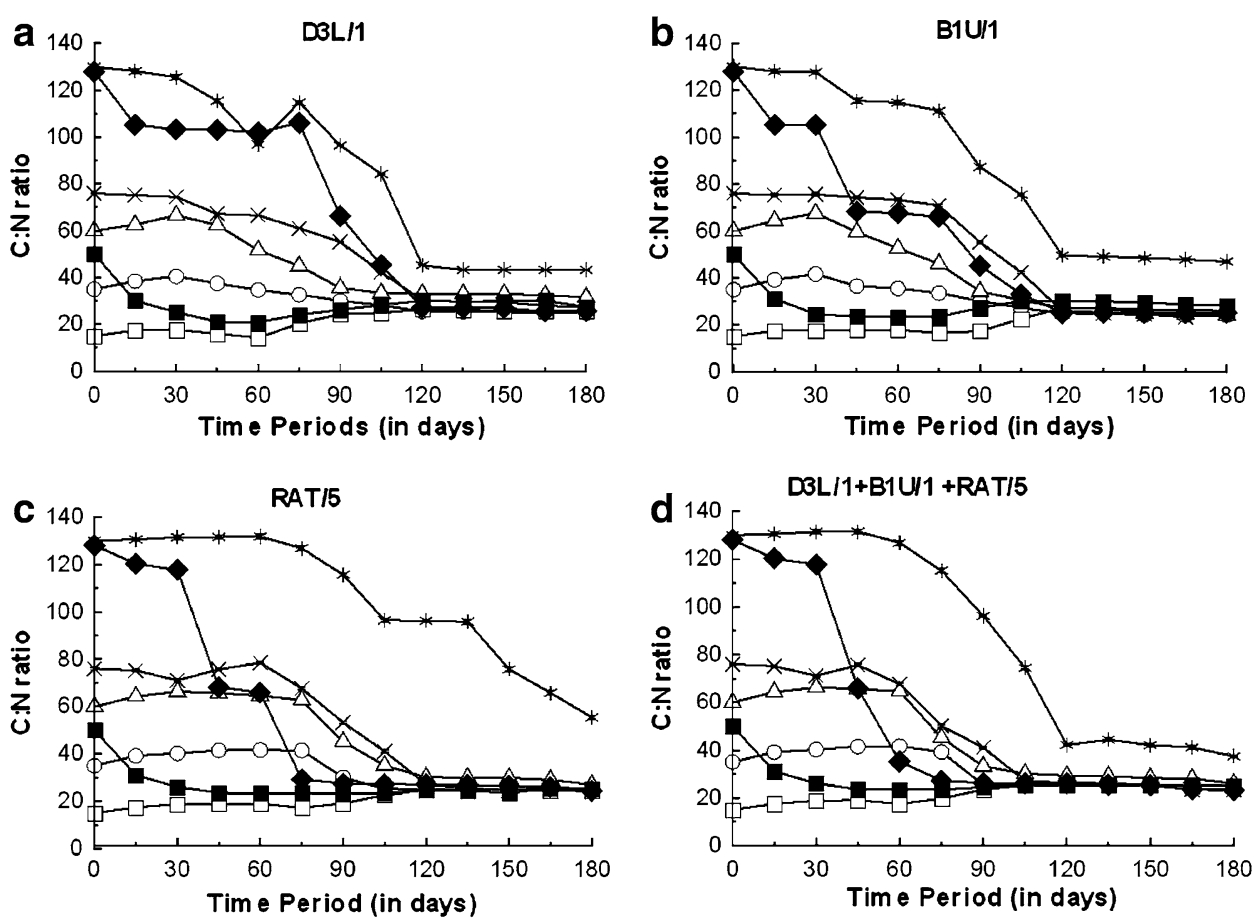


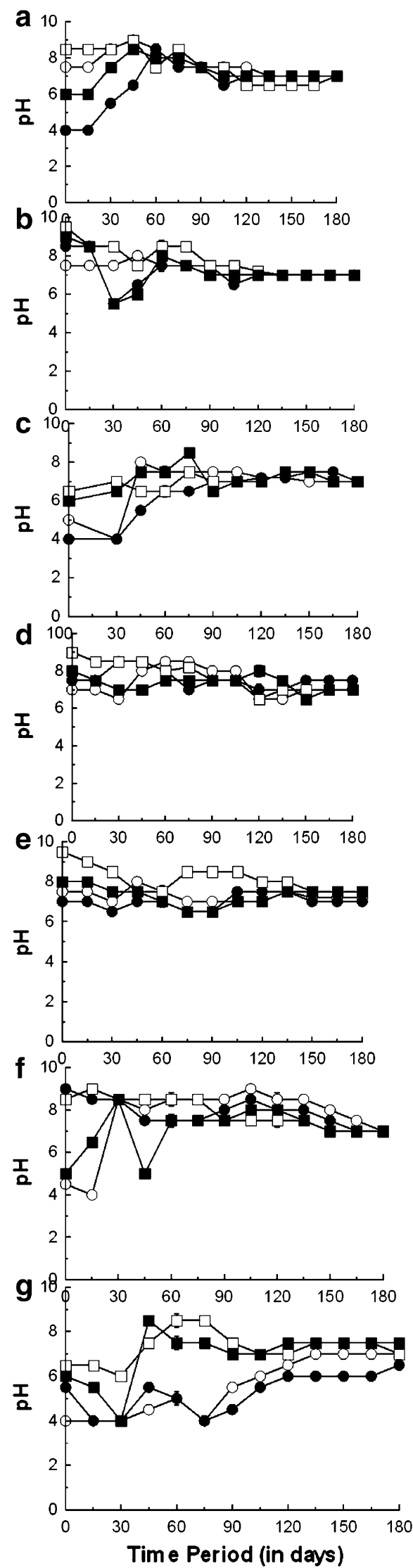

4Fig. 3 pH change during composting of different waste substrates: a fruit waste; $\mathbf{b}$ vegetable waste; c leaves; $\mathbf{d}$ hay; e newspaper waste; f wheat straw; $\mathbf{g}$ rice husks. Data are the mean of three independent experiments

at close to 7.0 after 120 days of composting for all substrates, except the wheat straw (Fig. 3d), which achieved a neutral $\mathrm{pH}$ after at 90 days.

\section{Phosphate ion concentration}

Throughout the composting process, the phosphate ion concentration varied between 6.8 and $47.46 \mathrm{mg} / \mathrm{kg}$, depending on the substrate and inoculum (Fig. 4). The lowest phosphate ion concentrations were measured for substrate C7 (rice husks; inoculated with isolate D3L/1, Fig. 4a), while the maximum concentration was measured for substrate C5 (newspaper waste; inoculated with Psudomonas sp RAT/5, Fig. 4c). The phosphate ion concentration remained constant for substrates $\mathrm{C} 1$ (fruit waste; with $B$. subtilis D3L/1, Fig. 4a) and C4 (hay; with B. subtilis B1U/1, Fig. 4b). Dinel et al. (2004) reported that nitrogen deficiency of the substrate could be improved by the addition of phosphoric acid, which could also prevent the excessive volatilization of ammonia. Phosphorus is sometimes applied during composting to maintain a $\mathrm{C}: \mathrm{P}$ ratio between 75:1 and 150:1 (Taiwo and Oso 2004; Gautam et al. 2010). A high percentage of the phosphate present in compost is available during the plant growing season, but nutrient availability depends on the quality of soil, particularly its moisture content and temperature (Hue et al. 1994; Wen et al. 1997), and the ready availability of phosphate enhances soil carbon and nutrient uptakes (Yadav et al. 1999).

\section{Statistical analysis}

Statistical analysis of all the biological parameters revealed that the consortia decomposed the raw material within a very short time period. However, among the different raw materials, wheat straw decomposed rapidly to correlate between microbial colonization and rate of decomposition.

\section{Conclusion}

There are many efficient hydrolytic bacteria and other physiologically important microorganisms present in compost. Several isolates from the Bacilli and Pseudomonas genera were selected based on their hydrolytic potentials for this study. The isolates were applied as a starter culture in the composting of various organic waste substrates, and a consortium of the inoculants (in a 1:1:1 ratio)
C1: Fruit wastes C2: Vegetable wastes C3: Leaves C4 : Hay C5: Paper waste C6: Whe at straw C7: Husk 
Fig. 4 Changes in the phosphate ion concentration during composting. Data are the mean value of three independent experiments a

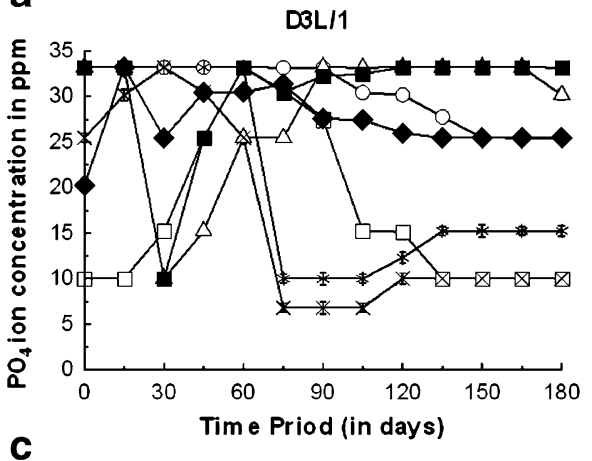

C

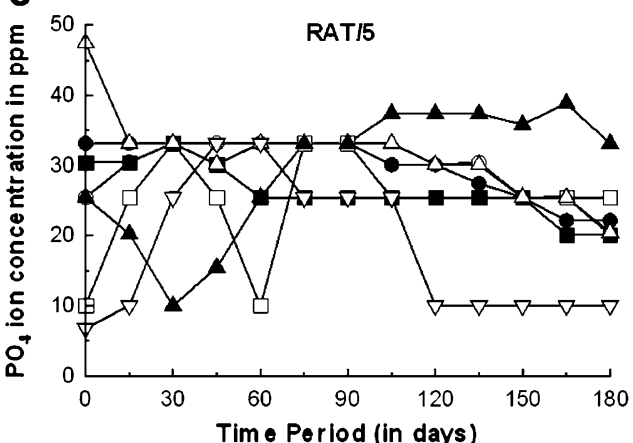

b

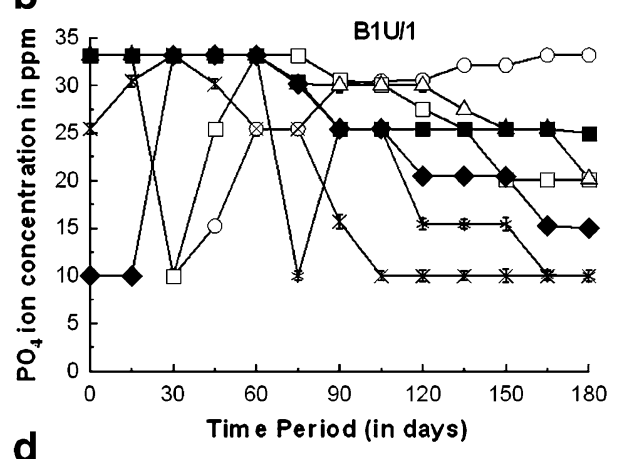

d

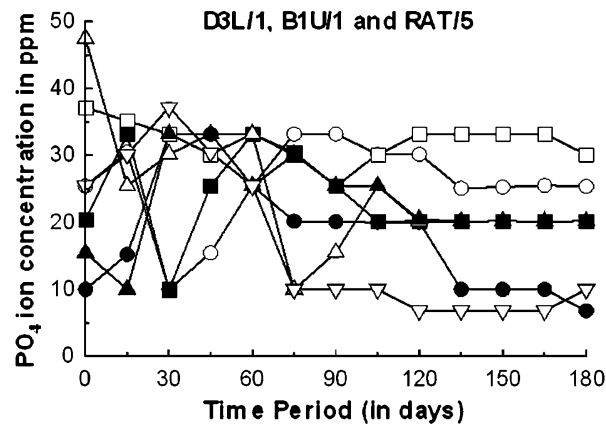

$-0-$ C1 Fruit waste $-C 2$ Vegetable
- c3 Leaves

\section{References}

was able to efficiently decompose all the substrates tested. The chemical composition of end products, even from the initial experimental stage, was consistent with national and international standards for composting (Hogg et al. 2000).

For successful composting, the selection of the most appropriate raw material is an important component (Fourti et al. 2011). Of the substrates tested, wheat straw was the most suitable material for large scale composting using the bacterial consortium, and this substrate is readily available and very cheap. With the consortium including both cellulolytic and nitrogen fixing bacteria, the rate of decomposition with wheat straw was maximized the compost was stable after 75 days, with a $\mathrm{pH}$ value of $7.0 \pm 0.2$ and a $\mathrm{C}: \mathrm{N}$ ratio close to $25: 1$. The experimental results indicate that the consortium is more effective than any individual isolate. The data show enough promise in the sustainable production of organic fertilizer using the consortium to instigate a pilot plant experiment.

Acknowledgments The authors are grateful to UGC, New Delhi for necessary funding (2011-14), and also to the Department of Botany (DST-FIST and UGC-DRS, New Delhi, India supported), VisvaBharati, Santiniketan, India.

Open Access This article is distributed under the terms of the Creative Commons Attribution License which permits any use, distribution and reproduction in any medium, provided the original author(s) and source are credited.
Alexander R (1999) Compost markets grow with environmental applications. Bio Cycle Mag 40:43-44

Al-Turki AI (2010) Quality assessment of commercially produced composts in Saudi Arabia market. Int J Agric Res 5:70-79

Anastasi A, Varese GC, Marchisio VF (2005) Isolation and identification of fungal communities in compost and vermicompost. Mycologia 97:33-44

Andrea C, Salvia S, Gianni Z (1998) Efficiency of backyard composting. Bio Cycle J 39:76-78

Anson ML (1938) The estimation of pepsin, trypsin, papain and cathepsin with haemoglobin. J Gen Physiol 22:79-89

Atkinson CF, Jones DD, Gauthier JJ (1996) Biodegradability and microbial activities during composting of poultry litter. Poult Sci 75:608-617

Benito M, Masaguer A, Moliner A, Arrigo N, Palma RM (2003) Chemical and microbiological parameters for the characterization of the stability and maturity of pruning waste compost. Biol Fert Soils 37:184-189

Bhiday MR (1994) Earthworms in agriculture. Indian Farm 43:31-34

Black CA (1965) Methods of soil analysis, vol 2. American Society of Agronomy, USA

Buyuksonmez F, Rynk R, Hess TG, Bechinski E (2000) Occurrence, degradation and fate of pesticides during composting. Part II: occurrence and fate of pesticides in compost and composting systems. Compost Sci Util 8:61-81

Chefetz B, Hatcher PG, Hadar Y, Chen Y (1998) Characterization of dissolved organic matter extracted from composted municipal solid waste. Soil Sci Soc Am J 62:326-332

Christian AH, Evanylo GK, Green R (1997) Compost: what is it and what's it to you? Virginia Cooperative Extension Service Publication, pp 452-231 
Dinel H, Marche T, Schnitzer M, Pre T, Champagne P (2004) Co composting of papers mill sludge and hardwood sawdust under two types of in-vessel processes. J Environ Sci Health B Pest Food Contam Agric Waste 39(1b):139-151

Erickson MC, Liao J, Ma L, Jiang X, Doyle MP (2009) Inactivation of Salmonella spp. In crow manure composts formulated to different initial C:N ratios. Biores Technol 100:5898-5903

Fourti O, Jedidi N, Hassen A (2011) Comparison of methods for evaluating stability and maturity of co-composting of municipal solid wastes and sewage sludge in semi-arid pedo-climatic condition. Nat Sci 3:124-135

Gautam SP, Bundela PS, Pandey AK, Awasthi MK, Sarsaiya S (2010) Composting of municipal solid waste of Jabalpur city. Global J Environ Res 4:43-46

Gillet R (1986) Traité de gestion des déchets solides and son application aux pays en voie de développement. Les traitements industriels des ordures ménagères et desdéchets assimilés. Organisation et gestion d'un service. p 538

Hadas A, Portnoy R (1994) Nitrogen and carbon mineralization rates of composted manures incubated in soil. J Environ Qual 23:1184-1189

Hardy V, Klaus F, Thomas T (1993) Quality physical characteristics nutriment content heavy metals and organic chemicals in biogenic waste compost. Compost Sci Util 1:69-87

Haug RT (1993) Development of simulation models. In: The Practical handbook of compost engineering, Lewis Publishers, Boca Raton, pp 385-436

Hellmann B, Zelles L, Palojarvi A, Bai Q (1997) Emission of climaterelevant trace gases and succession of microbial communities during open-windrow composting. App Environ Microbiol 63:1011-1018

Hogg D, Barth J, Favoino E, Centemero M, Caimi V, Amlinger F, Devliegner W, Briton W, Antler S (2000) Review of compost standards in the United States. The Waste and Resource Action Programme, Banbury

Hue NV, Ikawa H, Silva JA (1994) Increasing plant-available phosphorus in an ultisol with a yard-waste compost. Commun Soil Sci Plant Anal 25:3291-3303

Ishii K, Fukui M, Takii S (2000) Microbial succession during a composting process as evaluated by denaturing gradient gel electrophoresis analysis. J Appl Microbiol 89:768-777

Jackson ML (1968) Soil chemical analysis. Prentice-Hall, London

Kaosol T (2009) Sustainable solutions for municipal solid waste management in Thailand. World Acad Sci Eng Technol 60:665-670

Lasaridi KE, Stentiford ED (1996) Respirometric techniques in the context of compost stability assessment: principles and practice. In: de Bertoldi $\mathrm{M}$ et al (eds) The science of composting. Part 1. Blakie Academic \& Professional, London, pp 567-576

Lowry OH, Rosebrough NJ, Farr AL (1951) Protein measurement with the Folin phenol reagent. J Biol Chem 193:265-275

Mckinley VL, Vestal RJ (1985) Physical and chemical correlates of microbial activity and biomass in composting municipal sewage sludge. Appl Environ Microbiol 50:1395-1403

Miller GL (1959) Use of dinitrosalicylic acid reagent for determination of reducing sugar. Anal Chem 3:426-428

Nagavallemma KP, Wani SP, Stephane L, Padmaja VV, Vineela C, Babu Rao M, Sahrawat KL (2006) Vermicomposting: recycling wastes into valuable organic fertilizer, vol 2. An open access journal published by ICRISAT. $\mathrm{p} 16$

Novinsak A, Surette C, Allain C, Filion M (2008) Application of molecular technologies to monitor the microbial content of biosolids and composted biosolids. Water Sci Technol 57:471-477

Pearson WR, Lipman DJ (1988) Improved tools for biological sequence comparison. Proc Natl Acad Sci USA 85:2444-2448

Pedro MS, Haruta S, Nakamura K, Hazaka M, Ishii M, Igarashi Y (2003) Isolation and characterization of predominant microorganism during decomposition of waste materials in a field-scale composter. J Biosci Bioeng 95:368-373

Poincelot RP (1974) A scientific examination of the principles and practice of composting. Compost Sci 15:24-31

Ranalli G, Botturea G, Taddei P, Garavni M, Marchetti R, Sorlini G (2001) Composting of solid and sludge residues from agricultural and food industries bioindicators of monitoring and compost maturing. J Environ Sci Health 36:415-436

Saidi N, Cherif M, Jedidi N, Fumio M, Boudabous A, Hassen A (2008) Evolution of biochemical parameters during composting of various waste compost. Afr J Environ Sci 4:332-341

Sanmanee N, Panishkan K, Obsuwan K, Dharmvanij S (2011) Study of compost maturity during humification process using UVspectroscopy. World Acad Sci Eng Technol 80:403-405

Schloss PD, Hay AG, Wilson DB, Walker LP (2003) Tracking temporal changes of bacterial community fingerprints during the initial stages of composting. FEMS Microbiol Ecol 46:1-9

Snedecor GW, Cochran WG (1980) Statical methods. Lowa State University Press, Ames

Steger K, Sjogren AM, Jarvis A, Jansson JK, Sundh I (2007) Development of compost maturity and Actinobacteria populations during full-scale composting of organic household waste. J Appl Microbiol 103:487-498

Taiwo LB, Oso BA (2004) Influence of composting techniques on microbial succession, temperature and $\mathrm{pH}$ in a composting municipal solid waste. Afr J Biotechnol 3:239-243

Umsakul K, Dissara Y, Srimuang N (2010) Chemical physical and microbiological changes during composting of the water hyacinth. Pak J Biol Sci 13:985-992

Vogel AI (1961) A textbook of quantitative inorganic analysis. Longman, Green

Wang CM, Changa CM, Watson ME, Dick WA, Chen Y, Hoitink HAJ (2004) Maturity indices of composted dairy and pig manures. Soil Biol Biochem 36:767-776

Wani SP, Rupela OP, Lee KK (1995) Sustainable agriculture in the semi-arid tropics through biological nitrogen fixation in grain legumes. Plant Soil 174:29-49

Wen G, Bates TE, Voroney RP, Winter JP, Schellenbert MP (1997) Comparison of phosphorus availability with application of sewage sludge, sludge compost, and manure compost. Commun Soil Sci Plant Anal 28:1481-1497

White PR, Franke M, Hindle P (1995) Integrated solid waste management: a lifecycle inventory. Chapman and hall, London

Wu L, Ma LQ (2002) Relationship between compost stability and extractable organic carbon. J Environ Qual 31:1323-1328

Yadav RS, Lalit DL, Yadav BL, Baser BL (1999) Effect of conjunctive application of rock phosphate pyrites and farmyard manure on physical properties of Alfisol and yield of wheat (Triticum aestivum L.). Ann Arid Zone 38:145-149

Zeinhom EA, Elhadary R, Elashry A (2010) Integrating GIS and MCDM to deal with landfill site selection. Int J Eng Technol 10:32-42

Zeng G, Yu Z, Chen Y, Zhang J, Li H, Yu M, Zhao M (2011) Response of compost maturity and microbial community composition to pentachlorophenol (PCP)-contaminated soil during composting. Biores Technol 102:5905-5911 